\title{
Correction to: An improved quadrilateral finite element for nonlinear second-order strain gradient elastic Kirchhoff plates
}

Bishweshwar Babu • B. P. Patel

Published online: 28 January 2020

(C) Springer Nature B.V. 2020

1 Correction to: Meccanica

Publisher's Note Springer Nature remains neutral with regard to jurisdictional claims in published maps and institutional affiliations.

https://doi.org/10.1007/s11012-019-01087-z

This article was published with an erroneous version of Eq. 6 and therefore has been corrected.

B. Babu · B. P. Patel (ه) Department of Applied Mechanics, Indian Institute of Technology Delhi, New Delhi 110016, India e-mail: bppatel@am.iitd.ac.in 